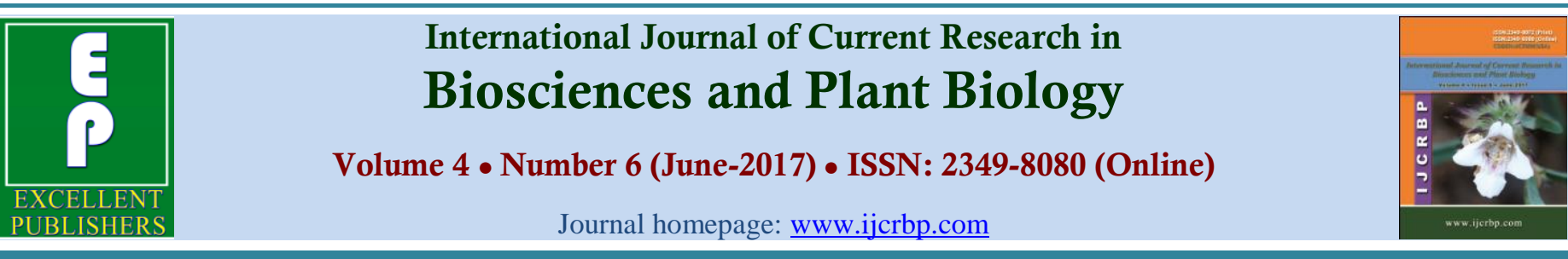

\title{
Diopsids (Diopsis thoracica and D. apicalis) Damaging Rice Production in Africa: A Review
}

\author{
Bocco Roland ${ }^{1}$, Gandonou Christophe Bernard ${ }^{1}$, Dannon Ayitondji Elie ${ }^{2}$ and \\ Zanklan Ahissou Séraphin ${ }^{1}$
}

\begin{abstract}
${ }^{1}$ Laboratoire de Physiologie Végétale et d'Etude des Stress Environnementaux. Faculté des Sciences et Techniques (FAST). Université d'Abomey-Calavi (UAC), 06 BP 1442 Cotonou, Bénin

${ }^{2}$ Ecole Normale Supérieure de Natitingou, Université Nationale des Sciences, Technologies, Ingénierie et Mathématiques (UNSTIM), 08 BP 0932 Cotonou, Bénin
\end{abstract}

*Corresponding author.

\begin{tabular}{|c|c|}
\hline Abstract & Article Info \\
\hline \multirow{8}{*}{$\begin{array}{l}\text { Diopsids are pests responsible for significant losses in rice and other cereal crop } \\
\text { production. Damages resulting from this attack particularly during tillering and flowering } \\
\text { stage are fatal. Research studies have been undertaken since 1950s in West Africa for } \\
\text { effective control and eradication of these enemies. Chemical control however became } \\
\text { predominant because insects were considered sporadic. Diopsids are dipterans that are } \\
\text { prolific under high humidity and near water points such as lowlands. Climate change } \\
\text { characterized by heavy rainfall, increased temperature and water volume associated to } \\
\text { uncontrolled flooding are in favor of their increase. In recent years, diopsids has spread in } \\
\text { virtually all rice growing ecologies. These insects are hosted by wild rice species such as } \\
\text { Oryza longistaminata and other plants in humid regions in the absence of rice crop. } \\
\text { Research has shown the influence of climatic factors and alternative hosts in the } \\
\text { expansion of these pests. Some resistant varieties belonging mainly to the species } O \text {. } \\
\text { glaberrima as CG14 have been identified. Breeding showed a transmissibility of this } \\
\text { resistance to the nrogenies as NFRICA4 }\end{array}$} & $\begin{array}{l}\text { Accepted: } 22 \text { May } 2017 \\
\text { Available Online: 06 June } 2017\end{array}$ \\
\hline & Keywords \\
\hline & Climate change \\
\hline & Diopsis apicalis \\
\hline & Diopsis thoracica \\
\hline & Deadhearts \\
\hline & Oryza glaberrima \\
\hline & Oryza longistaminata \\
\hline
\end{tabular}

\section{Introduction}

Diopsids or stalk flies are Dipterans which larvae or maggots are very detrimental to rice plants (Heinrichs and Barrion, 2004). They are present in all the rice ecologies of inter-tropical Africa (Brenière, 1983), but preferably in shady and humid areas such as lowland paddy fields (Olalekan, 2002); and irrigated rice fields (Heinrichs and Barrion, 2004). In heavily infested fields, damage can induce a loss ranging from $60 \%$ to $100 \%$
(Scheibelreiter, 1974; Heinrichs and Barrion, 2004). Occurrence of diopsids is usually considered as sporadic phenomenon and it is localized in many regions (Cochereau, 1978). Thus, many authors believed that economic losses due to diopsids occurred irregularly (Heinrichs, 2000). However, these insects have spread to several countries in Sub Saharan Africa (SSA), due to favorable climate conditions (Banwo, 2002; Togola et al., 2010; Weelar et al., 2016; Weelar et al., 2017). The proliferation of these insects causes alarming decrease in 
rice yields through increased damage of rice crop. The presence of diopsids on irrigated rice has long been reported in Benin (Brenière, 1976) but neither the populations of peduncle flies nor their damage were as important as they are nowadays (Togola et al., 2011b).

This review of the literature aims to summarize the various research studies carried out on diopsids for the protection of rice in order to achieve food security.

\section{General knowledge on diopsids damaging rice}

\section{Description of the main species}

At least three species of the genus Diopsis are recognized as enemies of cultivated rice. These are Diopsis longicornis, D. apicalis and D. collaris; D. longicornis is considered to be the most important (Heinrichs, 2000). The species D. thoracica and D. macrophthalma are synonymous with $D$. longicornis; while $D$. tenuipes is synonymous with $D$. apicalis (Feijen, 1985 quoted by Heinrichs, 2000). The two species (D. thoracica and D. apicalis) are the most

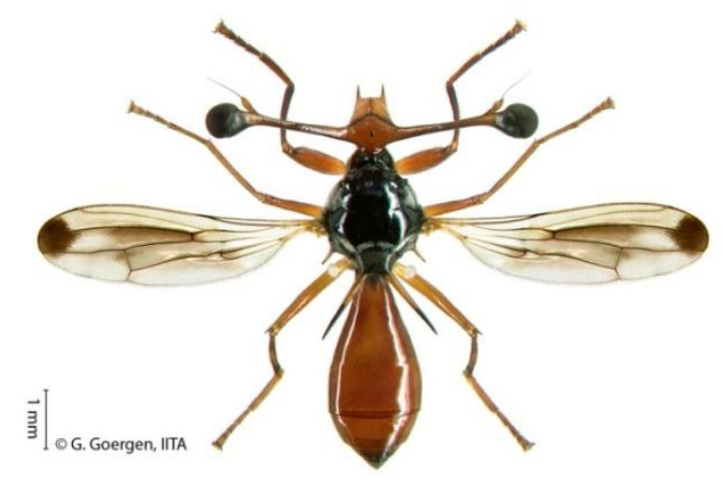

Fig. 1: Diopsis apicalis Source: Insectarium of IITA

\section{Geographical distribution of diopsids affecting rice}

The abundance of stem borers varies according to site, climatic zone and ecology. Diopsids are highly populated and prolific (Heinrichs, 2000). They are extensively distributed across the humid, equatorial and eastern tropical zones of Africa. Their presence and fast spread have been reported in several African countries. It has reportedly caused remarkable damages in Côte d'Ivoire and Benin, especially in irrigated and lowland rice, though much less in upland rice fields (Pollet, 1977; Alam, 1984); in rice fields in southern Casamance in Senegal (Appert, 1964; Vercambre, 1982); and in prevalent in rice fields and are largely dominant compared to many other species of diopsids present in the area (Cochereau, 1978). Figs. 1 and 2 show the two species that affect rice plants the more.

Given the great diversity within the species, Feijen in 1985 (quoted by Heinrichs, 2000) thought that a thorough systematic study of the genus Diopsis, could certainly reveal other unidentified species of importance. Already, a systematic work by Feijen and Feijen (2012) on specimens from South Africa and Swaziland revealed two other species Diopsis eisentrauti and D. stuckenbergi sp. $n$. belonging to the same group as $D$. thoracica. These authors developed a key to discriminate the two individuals that were identified. These insects are widespread in the regions of Cameroon, the Democratic Republic of Congo, Gabon and Togo. Another subspecies Diopsis servillei Macquart in Africa was mentioned by Pathak and Khan (1994). These authors have also revealed the existence of two subspecies Diopsis circularis Macquart and Diopsis ichneumonea Linnaeus in Africa, belonging to the species Diopsis apicalis Dalman.

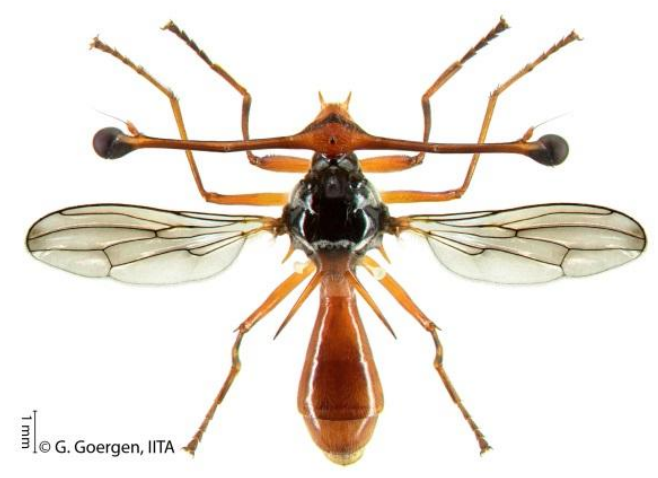

Fig. 2: Diopsis thoracica Source: Insectarium of IITA

Guinea (Chiasson and Hill, 1993). It is sporadic and limited to areas where there is sufficient moisture during the dry season in Burkina Faso and Mali (Brenière, 1983). However, distribution in Burkina Faso has been so extensive that it spurs; the creation of postage stamps bearing the effigy of diopsids as a major pest. It has been mentioned in Togo, Ghana, Cameroon, Liberia, Guinea, Sierra Leone, Guinea Bissau and Nigeria (Khan et al., 1991; Heinrichs, 2000). It is mentioned in Tanzania and Uganda where it extends in all the rice ecologies (Banwo, 2002; Weelar et al., 2016; Weelar et al., 2017). It was observed in Burundi and Rwanda where it regularly infects corn and rice fields (Tran, 
1981). Research in Kenya on the inventory of stem borers has reported $D$. thoracica in rice fields (Ho and Seshu Reddy, 1983). Similarly, its presence was reported in the Indian Ocean especially in Madagascar (Heinrichs and Barrion, 2004). From all the above, it becomes clear that SSA climates are conducive for proliferation of diopsids. Fig. 3 below shows the state of its dispersal in 1988 although an improved and updated map is needed to show the dispersion of the pest. This information gap reflects the lack of interest in this economically important pest whose control has become essentially chemical.

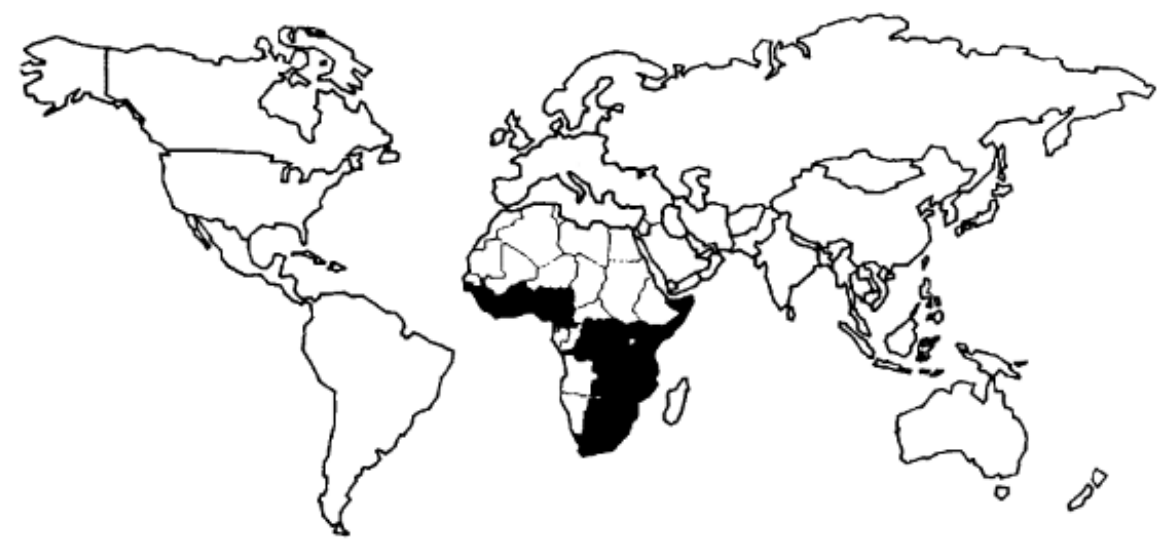

Fig. 3: Worldwide distribution of Diopsis thoracica (Alam, 1988).

\section{Biological cycle of diopsids}

The biological development cycle of Diopsis consists of the following stages:

- Egg: It has an elongated shape, with ribs, and has at one of its extremities a small fleshy excrescence.

- Larva: It is yellowish and characterized by two elongated abdominal extensions that are attached at the posterior extremities. It has black hooks which are bent forward.

- Cocoon: it is elongated, has a reddish-brown color and carries marked segmentations.

- Adult: It is large and can measure up to $10 \mathrm{~mm}$. Its thorax is glossy black, its wings transparent; the abdomen red-orange and covered with a fine dense hair.

The Fig. 4 below shows the development cycle of a diopsids.

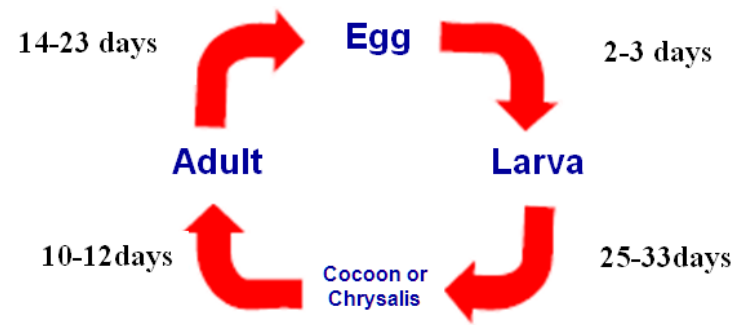

Fig. 4: Scheme of the biological cycle of a diopsids (Source: Wopereis et al., 2008).

\section{Biological development and damage of diopsids}

Each female lays an average of 30 isolated eggs for about 20 days with a maximum of 4 to 5 eggs per day. Incubation of the eggs lasts about 2 to 3 days. The life span varies accordingly: larva 25 to 33 days; pupa 10 to 12 , and the adult about 14 . The adult reaches the dry season in an immature state, grouped in swarms gathered near the permanent pools or preferably in shallow wetlands. From the first rains, sexual maturity is reached; mating and dispersal occur. Eventually, the insects land on rice plants. Often during the rainy season, the females lay eggs on young tiller leaves (Wopereis et al., 2008).

After hatching, the larva penetrates into the stem at the sheath and feeds only on healthy tissues (Wopereis et al., 2008). There is practically only one larva per damaged stem. Usually, the stem is cut at a distance of about 5-10 $\mathrm{cm}$ above the ground or water (Pathak and Khan, 1994). As the cut stem decomposes, the larva leaves the stem and passes on to a neighboring live stem, destroying 3-10 stems on average during its development (Heinrichs and Barrion, 2004). Pupation occurs inside the last colonized stem. The larva lives exclusively inside the stems during tillering stage. Exceptional late attacks may affect rice at heading but not beyond this stage. There can be only one generation of the insect during a cycle of rice in production. The adult insects from the previous generation look for 
young stems of rice. This exposes late crops to the attacks of the emerging generation of insects (Wopereis et al., 2008). Damage is estimated by the rate of attacked stems relative to the total number of tillers produced. In addition, compensating tillering is induced by the loss of tillers destroyed by a reaction of the plant. This mechanism depends on the precocity and intensity of the attack, the tillering capacity of the variety and its development conditions. Apparent "deadhearts" are often very abundant and it is not uncommon to find up to $80 \%$ of tillers attacked without significantly affecting the harvest (WARDA, 2000). This situation mentioned above is often observed on tolerant rice varieties with high tillering ability. Losses are difficult to be evaluated and severe when a high concentration of eggs is deposited from early tillering stage mainly at early cycle. However, with equal density of infestation, there are strong differences according to the varietal resistance and in particular according to its ability to produce tillers.

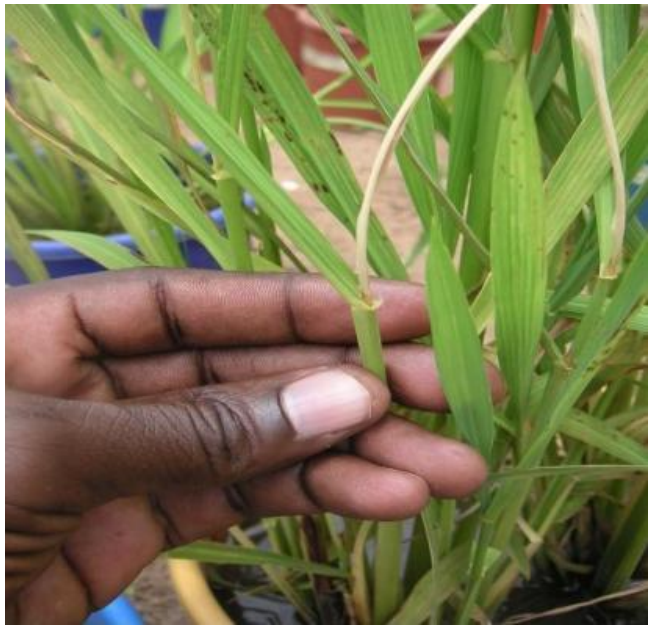

(a)

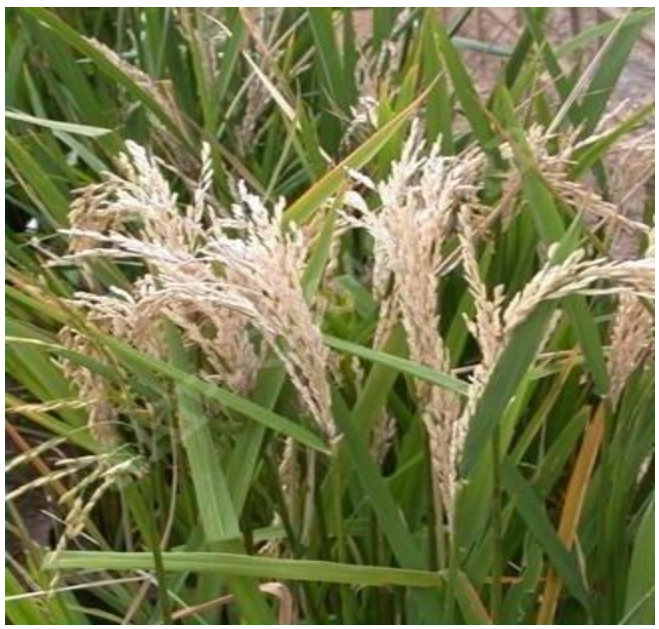

(b)

Fig. 5: Symptoms of deadhearts (a) and white panicles (b).

\section{Different methods for evaluating varieties subjected to diopsids}

\section{Former method of classification by Heinrichs et al.} (1985): In this approach, D. thoracica (deadhearts) infestation was previously assessed on plants between 45 and 50 days after transplantation (DAT). This was done by counting the total number of infested tillers in one hand and counting the total number of tillers per variety in the other hand. The percentage of deadhearts (X) is estimated using the following formula developed by Oñate (1965):

$\mathrm{X}=\mathrm{P}^{*} \overline{\mathrm{X}}_{\mathrm{nz}} *(100)$

Where,

$$
\begin{aligned}
\mathrm{P} & =\frac{\text { Total number of infested tillers per variety }}{\text { Total number of tillers per variety }} \\
\overline{\mathrm{X}}_{\mathrm{nZ}} & =\frac{\text { Nomber of infested tillers per variety } x \quad 100}{\text { Number of total tillers per variety }}
\end{aligned}
$$

$\mathrm{X}=$ Percentage of deadhearts
After defining the percentage of deadhearts (X) for each accession, the latter estimate is converted to the scale created for the evaluation of diopsids by Heinrichs et al. (1985). Table 1 below shows the trends for each scale.

Table 1. Standard for the classification of varieties subjected to diopsids according to Heinrichs et al. (1985).

\begin{tabular}{ll}
\hline $\mathbf{X}$ & Scale \\
\hline 0 & 0 \\
$1-4$ & 1 \\
$5-10$ & 3 \\
$11-25$ & 5 \\
$26-50$ & 7 \\
$51-100$ & 9 \\
\hline
\end{tabular}

Accessions ranged from 1 to 3 were considered resistant; those with a scale of 5 were considered moderately resistant; and those between 7 and 9 were considered to be susceptible.

The current reference system for classifying varieties against diopsids by IRRI (2002)

The severity of symptoms on rice varieties is calculated 
by the following formula:

$$
\text { Severity }=\frac{\text { Number of infested tillers } x 100}{\text { Number of total tillers present }}
$$

Table 2. Rice phenotypic evaluation grid for resistance to diopsids (IRRI, 2002).

\begin{tabular}{|c|c|c|}
\hline Score & $\begin{array}{l}\text { Percent of } \\
\text { infested tillers } \\
\text { (Severity) }\end{array}$ & Status \\
\hline 0 & No damage & $\begin{array}{l}\text { Highly resistant or immune } \\
\text { (HR) }\end{array}$ \\
\hline 1 & $1-10 \%$ & Resistant (R) \\
\hline 3 & $11-20 \%$ & Moderately resistant (MR) \\
\hline 5 & $21-30 \%$ & Moderately suscpetible (MS) \\
\hline 7 & $31-60 \%$ & Susceptible (S) \\
\hline 9 & $\begin{array}{l}61 \% \text { and } \\
\text { above }\end{array}$ & Highly susceptible (HS) \\
\hline
\end{tabular}

\section{Current rice control technique against diopsids}

(i) Early and synchronized seeding should be practiced to avoid periods coinciding with the onset of damage.

(ii) Appropriate distance between plants should be respected. Increased damage has been shown to evolve with an increase in plant density (Heinrichs and Barrion, 2004).

(iii) Plants should be fertilized with calcium silicate to strengthen the stem tissue to resist the larval mandible.

(iv) During harvesting very high stem stubs should be avoided.

(v) Good water management is necessary especially ensuring that water level covers the base of the stem to limit the penetration of the larva.

(vi) Keeping natural enemies: Spiders are the natural enemies of these flies.

(vii) Varietal control: the cultivar "WAB 115-921211-691-2" was reported in Uganda to trap Diopsis thoracica larvae with its hairy leaves. The possibilities of this form of control are mentioned in www.infonet-biovision.org-Rice.

(viii) Other studies revealed use of resistant varieties CG14, NERICA4, K85 and some accessions from O. glaberrima and TOG (Tropical Oryza glaberrima).

However, all these previous investigations could not show the type of resistance used by the various accessions. Research carried out at Africa Rice since 2013 has shown resistance of varieties CG14, RAM55,
TOG5681, NERICA1, NERICA4 and NERICA8 (Unpublished data). Similarly, this work has shown that the choice of hosts by diopsids is based on olfactory, visual and biochemical principles. This work concluded that the resistance of rice to diopsids also has a genetic basis (Bocco et al., publication in progress).

The control of diopsids in many countries is mainly chemical, particularly in Benin. In the localities of Koussin, Kinwédi and Lele; rice producers can abuse of chemicals when rice is in field (Togola et al., 2011b). In the case of heavy infestations by stem borers, spraying of phosphamidon at $300 \mathrm{~g} \mathrm{~m} . \mathrm{a} / \mathrm{ha}$ (active ingredient per hectare) was advocated (Autrique et al., 1989).

\section{Recent advances in research on diopsids in rice}

\section{Evaluation for resistance to $D$. thoracica by Alam (1988)}

A total of 3002 accessions of rice, including 2951 from the Oryza sativa group and 51 from the $O$. glaberrima were evaluated for resistance to $D$. thoracica. This evaluation showed infestation levels varying between 1.25 and $66.6 \%$ on all accessions evaluated. A second evaluation identified 8 accessions as resistant $(0.27 \%)$ of the large population and 10 accessions as moderately resistant $(0.33 \%)$ of the large population. This confirms the results of the first evaluation. The infestation in all accessions tested varied between 8.13 and $45.17 \%$. Table 3 shows the different resistant accessions obtained for all the 3002 that constitutes the whole population.

\section{Seasonal incidence and other alternative hosts of stem borers by Ba et al. (2008)}

The study of the seasonal incidence and its hosts in the absence of cultivated rice was made by monthly observations in the vegetation of Oryza longistaminata in Burkina Faso at three sites. For this purpose, 500 tillers were torn randomly and dissected. These results showed that in the absence of a rice crop, diopsids flies and other stem borers survive on $O$. longistaminata wild rice species. These hosts serve as a refuge for these insects throughout the year. The damage observed varied according to the specific fields, the seasons and the phenological stages of the plant. The highest percentage of white panicles was about $8 \%$ during the dry season. The relevant of these results lies on their contribution to good strategic management against insects. 
Table 3. Status of some varieties subjected to D. thoracica by Alam (1988).

\begin{tabular}{|c|c|c|c|}
\hline Designation & Species & Source & Status \\
\hline TOG 5560 & Oryza glaberrima & Nigeria & Resistant \\
\hline TOG 6324 & Oryza glaberrima & Liberia & Resistant \\
\hline TOG 6367 & Oryza glaberrima & Liberia & Resistant \\
\hline TOG 6368 & Oryza glaberrima & Liberia & Resistant \\
\hline TOG 6390 & Oryza glaberrima & Liberia & Resistant \\
\hline TOG 6392 & Oryza glaberrima & Liberia & Resistant \\
\hline TOG 6399 & Oryza glaberrima & Liberia & Resistant \\
\hline TOG 6481 & Oryza glaberrima & Liberia & Resistant \\
\hline TOG 6332 & Oryza glaberrima & Liberia & Moderately resistant \\
\hline TOG 6337 & Oryza glaberrima & Liberia & Moderately resistant \\
\hline TOG 6343 & Oryza glaberrima & Liberia & Moderately resistant \\
\hline TOG 6436 & Oryza glaberrima & Liberia & Moderately resistant \\
\hline TOG 6486 & Oryza glaberrima & Liberia & Moderately resistant \\
\hline TOG 6529 & Oryza glaberrima & Liberia & Moderately resistant \\
\hline ITA 121 & Oryza sativa & IITA (Nigeria) & Moderately resistant \\
\hline TOX 1838-2-8 & Oryza sativa & IITA (Nigeria) & Moderately resistant \\
\hline DJ 12-539-2 & Oryza sativa & Senegal & Moderately resistant \\
\hline HPU 741 & Oryza sativa & India & Moderately resistant \\
\hline OS 6 (Susceptible check) & Oryza sativa & Zaïre (D.R. Congo) & Susceptible \\
\hline
\end{tabular}

Host plants other than cultivated rice and screening on cultivated rice by Banwo (2002) and Togola et al. (2011a)

For Banwo (2002), Diopsis thoracica is not known to attack cultivated crops other than cultivated rice. Pest infestation delays normal growth and reduces the number of panicles. Adult insects live near water and aquatic plants and prefer shady environments. Consequently, D. thoracica can become a pest of economic importance in irrigated rice. This publication provides an update on the life history of the insect with particular emphasis on each stage of reproduction. The author mentioned that chemical treatment contributes effectively to the control of diopsids. He suggested that the most effective control method seems to be the use of systemic insecticides.

For another study, Togola et al. (2011a) aim to develop a method for the rapid detection of rice varieties for resistance to diopsids. This was to provide breeders with sources of resistance and to assist producers in the use of resistant varieties to reduce or avoid insecticidal treatments in the fields. The study was carried out at the Rice Center for Africa. In 2008, 18 interspecific upland NERICAs varieties and their parents (Oryza glaberrima and $O$. sativa) were first subjected to an artificial infestation of diopsids eggs and later to adults. The evaluation was based on the techniques of screening soya for resistance against Thrips pests using small cages. The results showed that NERICA16 and NERICA18 were resistant to the attack of diopsids at 20 days after infestation (DAI) when the inoculum was the eggs. In the case of infestation using the adult insect, the varieties NERICA18, NERICA11, NERICA6 and NERICA15 were very resistant, including the resistant parent CG14. This result confirmed the relevance of using adult insects in the case of a characterization for resistance to diopsids.

\section{Heritability of resistance to diopsids (Diopsis thoracica) by Weelar et al. (2017)}

Of the two species of diopsids, D. thoracica is the most widespread and most destructive. In order to determine the heritability of resistance to the ten diopsids in rice fields in Uganda, crosses were made between eight parental lines (NERICA4, TXD306, K85, NM7-22-11BP-1-1, NERICA1, NERICA6, NAMCHE2 and PAKISTAN). These varieties were selected according to their responses to diopsids, high yield and the precocity of their cycle. Among the eight rice varieties, four parental lines (NERICA4, TXD306 and NM7-22-11BP-1-1 and K85) displayed fewer deadhearts symptoms and were crossed with four susceptible genotypes (NERICA1, NERICA6, PAKISTAN and NAMCHE2).

GCA and SCA effects were significant for the 
percentage of deadhearts. Analysis showed that the additive and non-additive genetic's effects were associated with resistance to the stalk fly, although the non-additive genetic's effects were greater. NERICA4 and K85 have proved to be good donors for increasing resistance in progeny.

\section{Identification of new sources of resistance to diopsids (D. thoracica or D. apicalis) by Weelar et al. (2016)}

The main areas of rice cultivation in Uganda are affected. Specifically, the elite varieties cultivated by farmers are susceptible. The actual study attempted to identify sources of resistance to diopsids among improved rice genotypes in Uganda. Fifty genotypes were screened under cage and field conditions at the National Crops Resources Research Institute (NaCRRI) in Uganda. Trials were carried out in an alpha-lattice design, with 3 replications, for both experiments. Natural infestation (D. longicornis or D. apicalis) was used in the field while cage trials utilized artificial infestation with $D$. longicornis. Data on deadhearts were collected from seedling to tillering stages, at 7, 14, 21 and 28 days after transplanting. Infestation levels for 31 $(62 \%)$ rice genotypes were the same under both field and cage conditions.

Four rice genotypes (8\%) among the screened varieties showed higher susceptibility in the cage than in the field and $15(30 \%)$ were more resistant in the cage than in the field. Genotypes NERICA 4, TXD306, NM7-22-11B-P1-1 and K85 were identified as the most resistant varieties. F3 genotypes (GSR IR1- 5-S14-S2-Y1 × K85, Gigante $\times$ NERICA4, NERICA4 $\times$ Gigante, NERICA1 $\times$ NERICA4, NERICA4 $\times$ NERICA6, and NERICA4 $\times$ SUPA) were also found resistant. These genotypes were recommended for release and further advancement, respectively.

During another study, Togola et al. (2011b) assessed the influence of cultural practices on the sedentary of these flies affecting the irrigated rice field in Benin. For three consecutive years (2006, 2007 and 2008), the presence of diopsids was monitored in three irrigated perimeters (Lélé, Koussin and Kinwédji) using four agro systems (Ags), including rice plots at tillering and heading stages, rice ratoons and fallow. The results showed that the sites of Lélé and Kinwédi experienced a strong infestation during the three years, whereas that of Koussin kept a very small population of diopsids. Similarly, plots of rice at tillering stage $(\operatorname{Ags} 1 \mathrm{~b})$ and plots of ratoons (Ags2) were the most infested. The study identified the ratoons as one of the main causes of the sedentary of diopsids in crop areas. Integrated site management is recommended, taking into account the maintenance of the plots harvested.

\section{Perspectives}

Considering the urgency need to set up a plan to combat diopsids pest which has long been perceived as sporadic, certain prerequisites are necessary:

- A rapid and reliable technique for characterization of rice should be developed for its resistance against diopsids;

- It is important to determine the different bases of resistance of rice against diopsids;

- The identification of resistant varieties will enable the establishment of a varietal improvement program;

- A Marker-Assisted Selection (MAS) will help in the rapid creation of resistant varieties;

Finally, mapping and identification of resistance genes is required.

\section{Conclusion}

Diopsids are key insect pests reducing rice yield. The acclaimed sporadic nature of their damage implies that they had not benefitted much from research attention. The vagaries of climate change that induced erratic, rainfall, has encouraged the spread of this pest in many countries. They have moved from low interest insect status to the category of important pests. There have not been enough efforts to define the different bases of resistance of rice against diopsids. Recent work has shown the heritability of resistance and allowed the identification of some donors. Most of them come from the African rice species (Oryza glaberrima) and imply a rapid awareness of policy makers to encourage the exploitation of varietal resistance trait.

\section{Conflict of interest statement}

Authors declare that they have no conflict of interest.

\section{Acknowledgement}

The authors thank Mrs. Ogwuike Philomena Akalugo and Fidelia Babadjide to accept editing this review. 
They are also thankful to Dr. George Goergen of Biocontrol Center of IITA for providing the pictures of the insects.

\section{References}

Alam, M.S., 1984. Incidence of brown planthoper (BPH) and whitefly in Nigeria. Int. Rice Res. Newsl. 9(4), 13-14.

Alam, M.S., 1988. Evaluation of Rice Cultivars for Resistance to Diopsis longicornis (Diptera: Diopsidae). J. Econ. Entomol. 81(3), 934-936.

Appert, J., 1964. Les chenilles mineuses des céréales en Afrique tropicale. Agron. Trop. 19, 60-74.

Autrique, A., Perreaux, D., Goethals, M., 1989. Maladies et ravageurs des cultures de la région des grands lacs d'Afrique Centrale (No. 24). AGCD Coopération Belge. 232p.

Ba, N.M., Dakouo, D., Nacro, S., Karamage, F., 2008. Seasonal abundance of lepidopterous stem borers and diopsid fly in irrigated fields of cultivated (Oryza sativa L.) and wild rice (O. longistaminata Chev \& Roehr) in Western Burkina Faso. Int. J. Trop. Insect Sci. 28(01), 30-36.

Banwo, O.O., 2002. Management of major insect pests of rice in Tanzania. Plant Prot. Sci. 38(3), 108-113.

Breniere, J., 1976. Reconnaissance des principaux lepidopteres du riz de L' Afrique de l'Ouest. Agron. Trop. 31(3), 213-231.

Brenière, J., 1983. Principaux ennemis du riz en Afrique de l'Ouest et leur contrôle. $2^{\text {nd }}$ Edn. ADRAO, Monrovia, Liberia.

Chiasson, H., Hill, S.B., 1993. Population density, development and behaviour of Diopsis longicornis and D. apicalis (Diptera: Diopsidae) on rice in the Republic of Guinea. Bull. Entomol. Res. 83, 5-13.

Cochereau, P., 1978. Fluctuations des Populations Imaginales de «Diopsis thoracica» westwood et «Diopsis apicalis » Westwood «Diptera, diopsidae » en Liaison avec la Phénologie d'un riz de bas-fond à Bouaké (Côte d'Ivoire). Cahiers ORSTOM, Série Biologie. Entomol. Agric. 13(1), 45-58.

Feijen, H.R., 1985. The correct name of the African rice stem-boring Diopsidae (stalk-eyed fly). Int. Rice Res. Newsl. 10(5), 21.

Feijen, H.R., Feijen, C., 2012. A new species of Diopsis L. (Diptera: Diopsidae) from South Africa and Swaziland, and brief review of African species with a large apical wing spot. Afr. Invertebr. 53(1), 125142.

Heinrichs, E.A., 2000. Le riz en Afrique Occidentale dans les foreurs de Tiges de céréales en Afrique. In: Importance Economique, Systematique, Ennemis Naturels et Methodes de Lutte (Eds.: Polaszek, A., Delvare, G. CIRAD, Montpellier.

Heinrichs, E.A., Barrion, A.T., 2004. Rice feeding insects and selected natural enemies in West Africa, Biology, ecology identification. (Eds.: Hettel, G. P.). International Rice Research Institute, Philippines. $237 \mathrm{p}$.

Heinrichs, E.A., Medrano, F.G., Rapusas, H.R., 1985. Genetic evaluation for insect resistance in rice. IRRI, Los Banos, Lagna, Philippines. 356p.

Ho, D.T., Seshu Reddy, K.V., 1983. Monitoring of lepidopterous stem-borer population by pheromone and light traps. Insect Sci. Appl. 4, 19-23.

IRRI, 2002. Standard Evaluation System (SES) for Rice. International Rice Research Institute, Philippines. $65 \mathrm{p}$.

Khan, Z.R., Litsinger, J.A., Barrion, A.T., Villanueva, F.F.D., Fernandez, N.J., Taylo, L.D., 1991. World bibliography of rice stem borers 1794-1990. International Rice Research Institute and International Centre of Insect Physiology and Ecology. IRRI, Manila, Philippines.

Olalekan, O.B., 2002. Management of major insects' pests of rice in Tanzania (Review). Plant Prot. Sci. 38(3), 108-113.

Oñate, B.T., 1965. Estimation of stem borer damage in rice fields. Phili. Statis. 14(3), 201-221.

Pathak, M.D., Khan, Z.R., 1994. Insect pests of rice. IRRI and ICIPE, ISBN 971-22-0028-0. 5p.

Pollet, A., 1977. Species diversity and distribution of Scolytidae along the forest boundary in a forestsavanna mosaic belt of the Ivory Coast. Oikos. 29, 186-192.

Scheibelreiter, G., 1974. The importance of Diopsis tenuipes Westwood as a pest of rice, based on a comparison of the egg-laying behaviour of $D$. tenuipes and D. thoracica Westwood. Ghana J. Agric. Sci. 7, 143-145.

Togola, A., Agbaka, A., Agunbiade, T.A., Anato, F., Chougourou, D.C., Nwilene, F.E., 2010. Connaissance paysanne des insectes foreurs de tiges du riz et leurs dégâts dans différentes zones écologiques du Bénin (Afrique de l'Ouest). Cah Agric. 19, 262-267.

Togola, A., Nwilene, F.E., Agbaka, A., Degila, F., Tolulope, A., Chougourou, D., 2011a. Screening upland varieties of NERICA and its parents for resistance to stalk-eyed fly, Diopsis sp. (Diptera, Diopsidae) in Benin. J. Appl. Sci. 11(1), 145-150. 
Togola, A., Nwilene, F.E., Kone, B., Chouqourou, D., 2011b. Sédentarisation des populations des mouches Diopsides dans les agrosystèmes rizicoles au Benin. Tropicultura. 29(2), 101-106.

Tran, M., 1981. Reconnaissance des principaux foreurs des tiges du riz, du maïs et de la canne à sucre en Côte d'Ivoire. Travaux et documentations de l'Orstom, $\mathrm{n}^{\circ} 48$. Paris, Orstom éditions.

Vercambre, B., 1982. Diopsis thoracica West. (Dipt. Diopsidae), important ravageur du riz en Afrique de l'Ouest: données bio-écologiques et application à la lutte intégrée. Agron. Trop. 37, 89-98.

WARDA, 2000. Rapport annuel ADRAO 2000. Points saillants des activités. Une petite mouche à gros problèmes: la cécidomyie africaine des galles du riz. pp.20-26.

Weelar, C.G., Lamo, J., Otim, M.H., Awio, B., Ochwo-
Ssemakula, M., 2017. Mode of inheritance of resistance to the stalk-eyed fly (Diopsis longicornis) in rice. Int. J. Agron. Agric. Res. 10(1), 9-20.

Weelar, C.G., Otim, M.H., Lamo, J., Awio, B., OchwoSsemakula, M., 2016. Evaluation of rice genotypes for resistance to the stalk-eyed fly (Diopsis longicornis) in rice in Uganda. Int. J. Agron. Agric. Res. 9(2), 9-21.

Wopereis, M.C.S., Defoer, T., Idinoba, P., Diack, S. Dugué, M.-Jo., 2008. Curriculum d'apprentissage participatif et recherche action (APRA) pour la gestion intégrée de la culture de riz de bas-fonds (GIR) en Afrique subsaharienne. Référence 21 Les insectes de la culture de riz. Curriculum APRAGIR: Manuel technique. pp.92-103.

www.infonet-biovision.org-Rice, accessed April 2017.

\section{How to cite this article:}

Bocco, R., Gandonou C. B., Dannon, A. E., Zanklan, A. S., 2017. Diopsids (Diopsis thoracica and D. apicalis) damaging rice production in Africa: A review. Int. J. Curr. Res. Biosci. Plant Biol. 4(6), 33-41. doi: https://doi.org/10.20546/ijcrbp.2017.406.004 